\title{
TIME OF PRESENTATION OF STROKE PATIENTS IN SÃO PAULO HOSPITAL
}

\author{
José Fábio Santos Leopoldino, Marcia Maiumi Fukujima, \\ Gisele Sampaio Silva, Gilmar Fernandes do Prado
}

\begin{abstract}
With the advent of time-dependent thrombolytic therapy for ischemic stroke it has become increasingly important for stroke patients to arrive at the hospital quickly. This study investigated the time that our patients took since the recognition of the symptoms until the stroke diagnosis in a hospital in the city of São Paulo. We concluded that in our hospital medical personnel and paramedics did not consider stroke as a medical emergency before neurological evaluation. Social problems as lack of access to an effective emergency medical service are another important factor that was responsible for patient's delay. Our study was important in order to identify the problems that stroke patients face in our country until the diagnosis is established.
\end{abstract}

KEY WORDS: stroke, time of presentation.

\section{Tempo de chegada do paciente com acidente vascular cerebral no Hospital São Paulo}

\begin{abstract}
RESUMO - Com o uso da terapia trombolítica para acidente vascular cerebral (AVC) isquêmico, torna-se importante o tempo de chegada do paciente nos serviços de referência. Neste estudo foi investigado o tempo entre o reconhecimento dos sintomas e o diagnóstico de AVC em hospital universitário na cidade de São Paulo. Concluímos que neste serviço, os profissionais da saúde não consideravam AVC uma emergência antes da avaliação neurológica. Outro fator que contribuiu para o atraso na chegada ao hospital foi dificuldade de transporte aos serviços públicos. Este estudo foi importante para a identificação dos problemas que os pacientes com AVC enfrentam para ter o diagnóstico e tratamento, o que possibilitou implantação de programas para melhora do atendimento.
\end{abstract}

PALAVRAS-CHAVE: acidente vascular cerebral, tempo de ocorrência.

Thrombolytic therapy with recombinant tissue plasminogen activator (rt-PA) for acute ischemic stoke may provide benefit in long term outcome ${ }^{1}$. A potential limitation to the use of t-PA is the time required (3 hours within onset of ischemic stroke) to initiate the intravenous rt-PA infusion. The benefit of intravenous t-PA for acute ischemic stroke beyond 3 hours from onset is not established ${ }^{2}$. At this time it is very important to know the average time from emergency department arrival to diagnosis of acute ischemic stroke in our medical services.

This prospective study was undertaken to evaluate the time that our patients take since the recognition of the deficit until the neurological evaluation and the diagnosis of stroke.

\section{METHOD}

This study was undertaken at the Neurologic Emergency Unit of Hospital São Paulo (UNIFESP-Escola Paulista de Medicina) from March 1998 to April 1999. Our hospital in located at São Paulo city that comprises around ten million people. Patients who had diagnosis of stroke (ischemic or hemorrhagic) or transient ischemic attack (TIA), randomly chosen, were submitted to a written protocol that asked about chronological information regarding to the time of the initial symptoms, the time of coming and arriving to the hospital and the time for the first medical and neurological evaluation. Demographic characteristics, the mode of arrival, past medical history and time of cranial computed tomography (CT) were also analyzed.

\section{RESULTS}

A total of 59 patients were evaluated in this study. There were 32 men (54.23\%) and 27 (45.7\%) women; mean age was $64.32 \pm 15.69$ years (range: 20 to 90 years). According to the stroke type there were 50 ischemic stroke (84.74\%), 8 hemorrhagic stroke (13.55\%), and 1 TIA (1.69\%). Initial symptoms and signs presented were hemiparesis in 33 patients

Emergency Department of São Paulo Hospital, Escola Paulista de Medicina, São Paulo Federal University (EPM - UNIFESP), São Paulo SP, Brazil.

Received 27 August 2002, received in final form 30 October 2002. Accepted 9 November 2002. 
Table 1. Stroke type and presentation time.

\begin{tabular}{lcccccccc}
\hline & $<3$ hours & \multicolumn{2}{c}{$<$ hours } & $<24$ hours & \multicolumn{2}{c}{$>24$ hours } \\
\hline Type & $\mathrm{N}$ & $\%$ & $\mathrm{~N}$ & $\%$ & $\mathrm{~N}$ & $\%$ & $\mathrm{~N}$ & $\%$ \\
Ischemic $(\mathrm{n}=50)$ & 13 & 26.0 & 15 & 30.0 & 25 & 50.0 & 25 & 50.0 \\
Hemorrhagic $(\mathrm{n}=8)$ & 4 & 50.0 & 4 & 50.0 & 5 & 62.5 & 3 & 37.5 \\
TIA $(\mathrm{n}=1)$ & & & & & 1 & 100.0 & & \\
Total & 17 & 28.8 & 19 & 32.0 & 31 & 52.5 & 28 & 47.5 \\
\hline
\end{tabular}

(55.93\%), dysphasia / dysartria in 13 (22.03\%), facial palsy in $11(18.64 \%)$, impaired consciousness in 8 $(13.55 \%)$, sensory deficits in $7(11.86 \%)$, headache in $6(10.16 \%)$, monoparesis in $6(10.16 \%)$, confusion in $5(8.47 \%)$, vertigo in $4(6.77 \%)$, dysfagia in 4 $(6.77 \%)$, visual impairment in $2(3.38 \%)$, seizure in $2(3.38 \%)$, and ataxia in 1 patient $(1.69 \%)$.

The average time from the initial symptoms until hospital arrival was 18 hours and 46 minutes. Sixteen patients looked for medical care more than 48 hours after the ictus. Fourteen patients $(23.72 \%)$ could not tell the time of the first symptom. Seventeen patients $(28.81 \%)$ arrived at the medical service within 3 hours of the beginning of the deficit and 19 patients $(32.02 \%)$ within 6 hours. From the 39 patients that came to our service as the first place 15 (38.46\%) arrived at the hospital within three hours and 16 patients (41.02\%) within 6 hours (Table 1). The average time from the scene until the hospital was 1 hour and 30 minutes. Patients arrived by private transportation in 44 cases $(81.48 \%)$, ambulance in $7(12.96 \%)$ or public transportation (bus, metro, and train). The average time for neurological evaluation inside our hospital was 1 hour and 31 minutes. Only after 5 hours and 20 minutes of the arrival (average) the patients underwent a cranial CT scan.

\section{DISCUSSION}

The benefit of t-PA treatment given within 3 hours of stroke onset was convincingly demonstrated by the NINDS trial ${ }^{1}$. Successful stroke care begins with recognizing stroke as a medical emergency like acute myocardial infarction or severe trauma ${ }^{3}$. Our study was performed at the time that rt-PA was not approved for acute ischemic stroke in our country so that there was not a thrombolysis protocol in our service. The lack of awareness of stroke as an emergency by the victim or family in Brazil can be illustrated by the delay to seek immediate medical help seen in our patients. It is widely accepted by stroke physicians that the prompt and fast transportation to a stroke treatment facility is vital in providing early stroke care ${ }^{4}$. In our country the access to emergency medical services is not easy and this was shown by the fact that most of our patients came to the hospital by private transportation. Medical personnel and paramedics need to be trained in the recognition of symptoms and signs of acute stroke and the necessity of rapid neurological evaluation ${ }^{5,6}$. Our study showed a delay of one hour and fifty-one minutes for the initial neurologic evaluation showing that most physicians at the triage service did not consider stroke as an emergency. Written protocols for stroke are a prerequisite for standardized patient care $^{7}$. Checklists can be used to ensure that the protocols are implemented. Delayed access to early brain-imaging facilities in our cases was due to lack of a protocol that considered a narrow therapeutic window for stroke patients. Acute stroke is increasingly recognized as one of the leading factors of morbidity and mortality worlwilde ${ }^{7-9}$. Our study is important to help identifying the problems that stroke patients face in our country until the diagnosis is established. Only by analyzing our own data we will be able to provide stroke patients a standard care.

\section{REFERENCES}

1. The National Institute of Neurological Disorders and Stroke rt-PA Stroke Study Group. Tissue plasminogen activator for acute ischemic stroke. N Engl J Med 1995;333:1581-1587.

2. Schroeder E, Wayne D, Morris D, Evenson K, Hinn A. Determinants of use of emergency medical services in a population with stroke symptoms. Stroke 2000;31:2591-2596.

3. Castillo J, Dávalos A. Avances en el manejo del ictus agudo. Rev Neurol Barc 1999;29:617-622.

4. Culebras A, Kase CS, Masdeu JC, et al. Practice guidelines for the use of imaging in transient ischemic attacks and acute stroke. Stroke 1997;28:1480-1497.

5. Hacke W, Kaste M, Fieschi C, et al. Intravenous thrombolysis with recombinant tissue plasminogen activator for acute hemispheric stroke. The European Cooperative Acute Stroke Study (ECASS). JAMA 1995;274:1017-1025.

6. Kaste M, Olsen TS, Orgogozo JM, Bogousslavski J, Hacke W, for the EUSI Executive Committee. Organization of stroke care: education, stroke units and rehabilitation. Cerebrovasc Dis 2000;10(Suppl 3):1-11.

7. Barsan WG, Brott TG, Broderick JP, Haley EC, Levy DE, Marler JR. Time of hospital presentation with acute stroke. Arch Intern Med 1993;153:2558-2561.

8. Alberts M, Bertels C, Dawson D V. An analysis of time of presentation after stroke. JAMA 1990;263:65-68.

9. Fogelholm R, Murros K, Rissanen A, Ilmavirta M. Factors delaying hospital admission after acute stroke. Stroke 1996;27:398-401. 